\title{
Cloning of the Elk Common Glycoprotein $\alpha$-subunit and the FSH and LH $\beta$-subunit cDNAs
}

\author{
Rena J. CLARK ${ }^{1}$, Michael A. FURLAN ${ }^{2}$ and P. Jorge CHEDRESE ${ }^{2}$ \\ ${ }^{1)}$ Department of Veterinary Biomedical Sciences and ${ }^{2)}$ Department of Obstetrics, Gynecology \\ and Reproductive Sciences, University of Saskatchewan, Royal University Hospital, \\ Saskatoon, SK, Canada S7NOW8
}

\begin{abstract}
We report the nucleotide and deduced amino acid sequences of the pituitary glycoprotein hormone common $\alpha$-subunit, and the FSH and LH $\beta$-subunits of the elk (Cervus elaphus). These sequences were obtained by RT-PCR of pituitary gland polyadenylated RNA. A partial genomic fragment of the elk follicle stimulating hormone $\beta$-subunit was also amplified from genomic DNA and sequenced. These sequences show high similarity to other related domestic species, including sika deer, ovine, bovine, porcine and equine. The presently reported cDNAs were used as probes for Northern analysis of pituitary gland and muscle samples from elk and sheep. Mature mRNA transcripts of approximately 700, 1700 and 550 bases were expressed in the pituitary gland but not in muscle tissue, for the glycoprotein hormone common $\alpha$-subunit and FSH and LH $\beta$-subunits, respectively. These observations are consistent with reports for other related species. The genomic fragment of elk FSH $\beta$-subunit revealed an intronic microsatellite of 6 CT repeats, which differs from the 19 CT repeats documented for the sheep genomic sequence. We propose that differences in the CT repeats of the elk FSH $\beta$-subunit gene may be used as a marker for elk parentage testing. The elk DNA sequences presently reported represent a unique addition to the growing collection of the pituitary hormone genes for various vertebrates, which will facilitate evolutionary and phylogenetic studies of the gonadotropin genes. In addition, this information and the cloned cDNAs will be useful for studying seasonal expression of the elk pituitary glycoprotein genes.
\end{abstract}

Key words: Elk, Cervids, FSH, LH, Gene cloning

(J. Reprod. Dev. 51: 607-616, 2005)

$\mathbf{F}$ ollicle stimulating hormone (FSH) and luteinizing hormone (LH) are structurally related heterodimeric glycoproteins, composed of two subunits, $\alpha$ and $\beta$. The $\alpha$-subunit is common for both hormones, while the $\beta$-subunit is hormonespecific [1]. FSH and LH are produced by the gonadotrope cells of the pituitary gland and are essential for ovarian follicular development, maturation of the oocyte, steroidogenesis and ovulation. In males, LH is involved in regulation of

Accepted for publication: May 19, 2005

Published online: July 21, 2005

Correspondence: P. J. Chedrese

(e-mail: chedresj@duke.usask.ca) steroidogenesis in the Leydig cells, whereas FSH regulates spermatogensis by binding to receptors in the Sertoli cells [2]. The gene and protein structures of the pituitary glycoprotein hormones of a variety of vertebrates including, mammals, birds, amphibians and fish have been reported over recent years [3]. This information has been useful for the isolation and analysis of these genes in different species, identification and quantification of their mRNA and production of biologically active recombinant hormones. Analysis of the nucleotide and predicted amino acid sequences of the pituitary glycoproteins also provides further 
insight into the evolution of this family of hormones [4]. We are interested in studying expression of the gonadotropin genes in the North American elk, or wapiti (Cerous elaphus). The elk is a temperate seasonal breeder related to the Japanese water deer, or sika deer (Cervus nippon). The only information on cervid pituitary gene structures is the recently reported sika deer common $\alpha$-subunit [5] and FSH $\beta$-subunit [6] and our recently reported elk pre-prolactin cDNA [7]. We presently report the cloning and expression of the elk pituitary common glycoprotein $\alpha$-subunit and the FSH and LH $\beta$-subunit cDNAs and their deduced amino acid sequences. Overall, this work is aimed at generating information on the structure of the gonadotropin genes and developing the reagents for studying the molecular basis of the seasonal reproductive events in elk.

\section{Materials and Methods}

\section{Reagents}

TRI ${ }^{\circledR}$ Reagent, general chemicals, antibiotics and reagents for RNA electrophoresis, were purchased from Sigma (St. Louis, MO). Oligotex ${ }^{\circledR}$ and QiaexII ${ }^{\circledR}$ kits were purchased from Qiagen (Mississauga, ON). The FirstChoice ${ }^{\circledR}$ RLM-RACE kit was purchased from Ambion (Austin, TX). Hybond- $\mathrm{H}^{\circledR}$ nylon membranes were purchased from Amersham Pharmacia Biotech (Piscataway, $\mathrm{NJ}) . \quad\left[\alpha-{ }^{32} \mathrm{P}\right]-\mathrm{dCTP}$ was purchased from New England Nuclear (Boston, MA). Agarose, X-gal (5bromo-4-choro-3-indolyl-B-D-galactoside), Moloney murine leukemia virus reverse transcriptase (MMLV-RT), custom primers and EcoRI were purchased from GibcoBRL (Burlington, ON). Taq DNA polymerase (catalogue \#18038018), 10X PCR buffer, dNTPs and the TOPO TA ${ }^{\circledR}$ kit were purchased from Invitrogen (Carlsbad, CA).

\section{Purification and Northern blot analysis of mRNA}

Total RNA was isolated from pituitary glands of three female elk and one female sheep. Total RNA was also isolated from female elk muscle. Tissue samples were collected immediately after death and stored at $-80 \mathrm{C}$ until processed. Then samples were homogenized in TRI ${ }^{\circledR}$ Reagent with a Polytron ${ }^{\circledR}$ tissue homogenizer (Brinkmann, Mississauga, ON). Total RNA was extracted following the manufacture's protocol and dissolved in a solution containing $0.5 \%$ SDS and 20 $\mathrm{mM}$ EDTA. Ten $\mu \mathrm{g}$ of total RNA were sizefractionated by electrophoresis in an agarose/ formaldehyde gel, transferred to a nylon membrane by capillary blotting and cross-linked using a UV Stratalinker $1800^{\circledR}$ (Stratagene, La Jolla, CA). The cDNA probes were labelled by primer extension with $\left[\alpha{ }^{32} \mathrm{P}\right]-\mathrm{dCTP}(50 \mu \mathrm{Ci})$. Northern blot membranes were hybridized and autoradiographed as previously described [8].

\section{Synthesis, cloning and sequencing of the pituitary gonadotropin cDNAs}

Polyadenylated mRNA was obtained using the Oligote ${ }^{\circledR}$ kit following the manufacture's protocol. The common $\alpha$-subunit cDNA was amplified by polymerase chain reaction (PCR), using cDNA synthesised by RNA ligation mediated-rapid amplification of cDNA ends (RLM-RACE). The FSH and LH $\beta$-subunit cDNAs were amplified by PCR, using first strand cDNA synthesised with a chimeric oligo (dT) adapter primer and MMLV-RT. The custom primers were designed based on sequence homology to GenBank sequences, shown in Table 1. Genomic PCR was performed on white blood cell DNA extracted from whole blood samples following standard procedures [9].

The PCR mixture included $2 \mu \mathrm{l}$ of RT-cDNA, $5 \mu \mathrm{l}$ of the 10X PCR buffer, $4 \mu \mathrm{l}$ of $2.5 \mathrm{mM}$ dNTP, $2.5 \mu \mathrm{l}$ of $50 \mathrm{mM} \mathrm{MgCl} 2,50$ pmol of reverse and forward primers, and 1.5 units of Taq DNA polymerase. The cycling condition were (1) $94 \mathrm{C}$ for $3 \mathrm{~min}$, (2) $94 \mathrm{C}$ for $1 \mathrm{~min}$, (3) $65 \mathrm{C}$ for $1 \mathrm{~min}$, (4) $72 \mathrm{C}$ for $1.2 \mathrm{~min}$, (5) 30 cycles of steps 2 . 4, and (6) a terminal extension step at $72 \mathrm{C}$ for $7 \mathrm{~min}$. The amplified products were separated on a $1 \%$ agarose gel. The resulting band was excised from the gel and purified using the Qiaex II ${ }^{\circledR}$ kit, following the manufacturer's protocol and cloned into the TOPO TA ${ }^{\circledR}$ vector. Both strands of the isolated fragment were sequenced with vector-specific universal forward and reverse primers using a fluorescent automated sequencer (National Research Council, Plant Biotechnology Institute, Saskatoon, SK). Cloned cDNA were analysed and compared with sequences available in GenBank using the Clustal W alignment and Expasy translation public domain computer software (http://clustalw.genome.jp and http:// ca.expasy.org). 


\section{Results}

\section{Cloning of the pituitary glycoprotein common} $\alpha$-subunit cDNA

A 24 oligonucleotide forward primer was designed containing the putative common glycoprotein $\alpha$-subunit start codon (Table 1) based on the reported ovine cDNA nucleotide sequence [10]. Using this primer, and the 3' RACE reverse primer provided by the manufacturer, a DNA fragment of $691 \mathrm{bp}$ was amplified (Fig. 1). Sequencing of clones from three independent PCR revealed high similarity, between 85 and $95 \%$, to the glycoprotein common $\alpha$-subunit cDNA of other domestic species (Table 2). Comparison analysis suggests that $363 \mathrm{bp}$ of this fragment represent the entire coding region, and 309 bp represent the 3' untranslated region (UTR) including the polyadenylated tail of the mRNA. A deduced 120 amino acid peptide chain would be encoded by this nucleotide sequence (Fig. 1). The deduced amino acid sequence similarity between elk and a sub-set of related species is shown in Table 3.

\section{Cloning of the pituitary FSH $\beta$-subunit cDNA}

A 22 oligonucleotide forward primer, ending 5 bases upstream of the putative start codon, named forward FSH $\beta$-subunit (Table 1), was designed based on the reported ovine FSH $\beta$-subunit cDNA [11]. A 21 oligonucleotide reverse primer, named reverse FSH $\beta$-subunit primer 1, was designed to amplify within the putative coding region of the reported ovine cDNA (Table 1 ). With this set of primers, a fragment of $398 \mathrm{bp}$ was amplified. Sequencing analyses revealed high similarity to FSH $\beta$-subunit cDNA of sheep and other domestic species. We considered this to be a truncated cDNA, since the sequence ended 36 bp before the putative stop codon of the sheep FSH $\beta$-subunit cDNA. Therefore, to gain additional information on the last part of the elk FSH $\beta$-subunit genecoding region, a second set of primers were designed based on sheep genomic sequences [12]. A 23 oligonucleotide forward primer was designed based on intronic sequences located upstream of the second exon, and a 25 oligonucleotide reverse genomic primer was designed based on sequences located in the $3^{\prime}$ UTR of the gene, named genomic forward FSH $\beta$-subunit and genomic reverse FSH $\beta$-subunit, respectively (Table 1). Using this second set of primers we amplified a DNA fragment of 397 bp that included genomic sequences, containing 6 intronic CT microsatellite repeats and the last 237 $\mathrm{bp}$ of the coding region. Based on this information, a 26 oligonucleotide reverse primer was designed, named FSH $\beta$-subunit reverse primer 2 (Table 1), which was used with the forward FSH $\beta$-subunit primer. A DNA fragment of $414 \mathrm{bp}$ was amplified (Fig. 3), which demonstrated high similarity, between 88 and $93 \%$, to the FSH $\beta$-subunit cDNA of other domestic species (Table 2). This fragment included $390 \mathrm{bp}$, representing the entire coding region, excluding the $5^{\prime}$ and the $3^{\prime}$ UTR of the FSH $\beta$-subunit gene. Four PCR fragments were

Table 1. Oligonucleotide primers used for amplification of the pituitary glycoprotein cDNAs

\begin{tabular}{ll}
\hline \multicolumn{1}{c}{ Primer } & \multicolumn{1}{c}{ Sequence } \\
\hline Forward $\alpha$-subunit & 5' AGGCAGAGGACGAAGAGCCATGGA 3' \\
Reverse 3'RACE & 5' CGCGGATCCGAATTAATACGACTCACTATAGG 3' \\
Forward FSH $\beta$-subunit & 5' AGCATCCACAGTTACCAAGTGC 3' \\
Reverse FSH $\beta$-subunit primer 1 & 5' CTGAAGGAGCAGTAGCTGGGC 3' \\
Genomic Forward FSH $\beta$-subunit & 5' AGCAGTATTCAATCCCTGTCTCA 3' \\
Genomic Reverse FSH $\beta$-subunit & 5' CATGTACACACAGACAGCTTGGATG 3' \\
Forward FSH $\beta$-subunit & 5' AGCATCCACAGTTACCAAGTGC 3' \\
Reverse FSH $\beta$-subunit primer 2 & 5' TTACTCTCTGACGTCGCTGAAGGAGC 3' \\
Forward LH $\beta$-subunit & 5' GGTACCAGGCACCAAGGATGGAG 3' \\
Reverse LH $\beta$-subunit & 5' GGTACCAGGCACCAAGGATGGAG 3' \\
\hline
\end{tabular}

The forward $\alpha$-subunit primer was designed based on the NCBI X16977.1, ovine gonadotropin $\alpha$-subunit cDNA sequence. The forward and reverse FSH $\beta$-subunit primer 1 were designed based on the NCBI X15493.1, ovine FSH $\beta$-subunit cDNA sequence. The genomic forward and reverse FSH $\beta$-subunit primers were designed based on the NCBI S64745, ovine FSH $\beta$ genomic sequence. The reverse FSH $\beta$-subunit primer 2 was designed based on the presently reported elk FSH $\beta$ genomic sequence. The forward and reverse LH $\beta$-subunit primers were designed based on the NCBI S64695.1, ovine LH $\beta$-subunit cDNA sequence. 


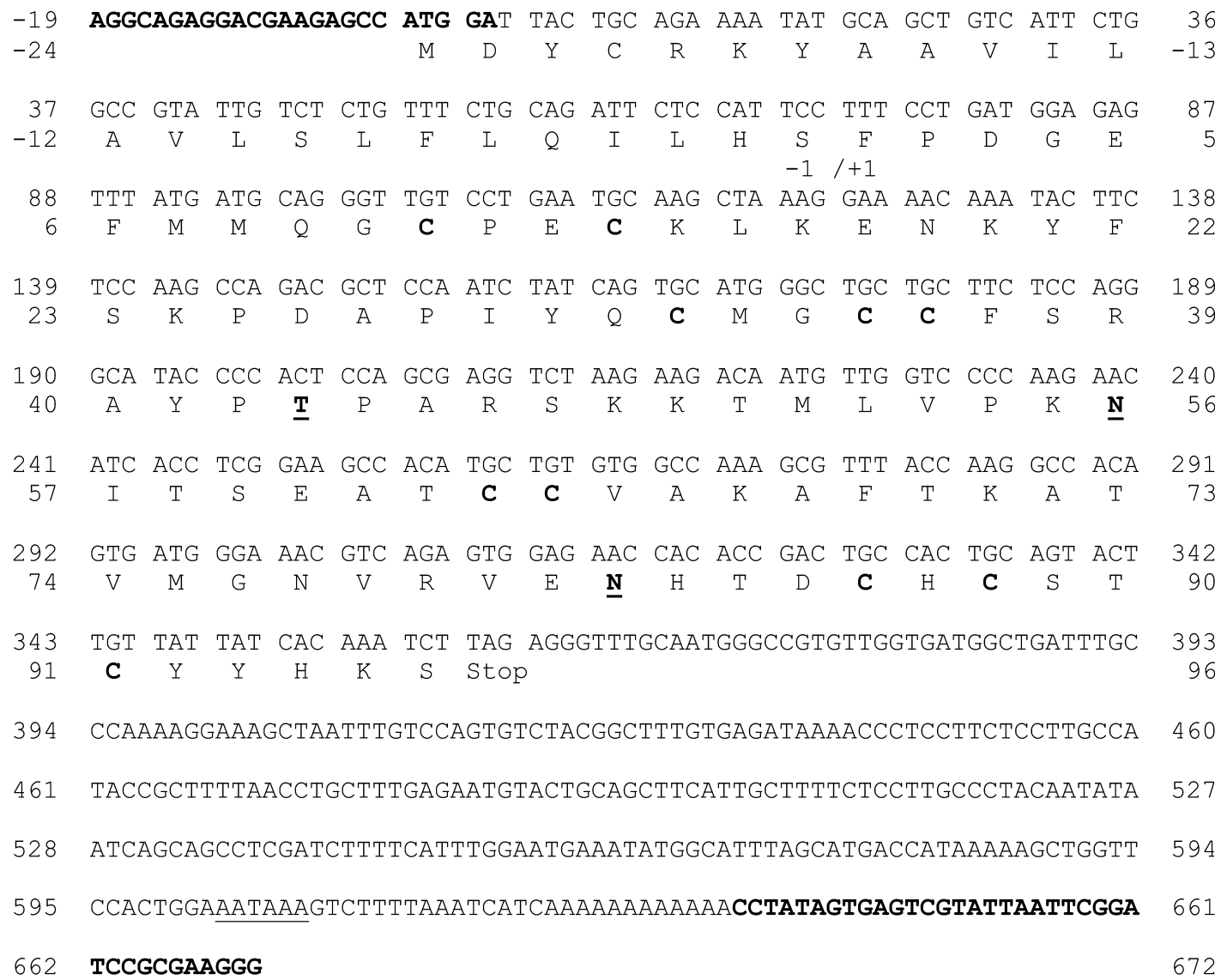

Fig. 1. cDNA nucleotide and deduced amino acid sequences of the elk common glycoprotein $\alpha$-subunit. The nucleotides of the $5^{\prime}$ UTR are designated with negative numbers and the first nucleotide of the ATG translational start codon as +1 . The forward custom primer was designed from nucleotide positions -19 to +5 , overlapping the first two codons from the translational start site. The primers sequences are shown in bold. The polyadenylation signal is underlined. The end of the signal peptide and the beginning of the mature protein amino acid sequence is designated as $-1 /+1$ boundary. The proposed leader sequence is 24 amino acids in length. The free $\alpha$-subunit is proposed to be $O$-glycosylated at $\mathrm{Thr}^{43}$, which is bolded and underlined. The $\alpha$-subunit in the heterodimeric glycoprotein is putatively $N$-glycosylated at Asn ${ }^{56}$ and $\mathrm{Asn}^{82}$, which are bolded and underlined. Proposed proper subunit folding involves 10 cysteines, shown in bold and located at positions $11,14,32,35,36,63,64,86,88$ and 91 that form 5 disulfide bonds.

sequenced, one truncated fragment from one animal, two genomic fragments from a second animal and one full-length fragment from a third animal. The sequence differences between the different elk are diagrammed in Fig. 3. A deduced 129 amino acid peptide chain would be encoded by this nucleotide sequence (Fig. 4). The deduced amino acid sequence similarity between elk and a sub-set of related species is shown in Table 3.

\section{Cloning of the pituitary LH $\beta$-subunit cDNA}

A 23 oligonucleotide forward primer was designed based on the reported ovine cDNA, containing the putative LH $\beta$-subunit start codon [13]. A 23 oligonucleotide reverse primer was designed to sequences located downstream of the putative stop codon, within the 3' UTR (Table 1). By using these primers a fragment of 524 bp was amplified, which revealed high similarity, between 79 and $97 \%$, to the LH $\beta$-subunit cDNA of other domestic species (Table 2). The elk LH $\beta$-subunit sequence was confirmed by sequence analysis of three independent PCR fragments. This sequence includes the entire coding region, with an open reading frame of $366 \mathrm{bp}$, which encodes a deduced peptide chain of 121 amino acids (Fig. 5). The 
Table 2. Nucleotide similarities between the elk glycoprotein cDNAs and cDNAs from a subset of related species were examined over the entire coding region

\begin{tabular}{|c|c|c|c|}
\hline & $\begin{array}{l}\text { Elk gonadotropin } \\
\alpha \text {-subunit cDNA } \\
\text { (363 bases) }\end{array}$ & $\begin{array}{c}\text { Elk FSH } \\
\beta \text {-subunit cDNA } \\
\text { (390 bases) }\end{array}$ & $\begin{array}{c}\text { Elk LH } \\
\beta \text {-subunit cDNA } \\
(426 \text { bases })\end{array}$ \\
\hline Sika deer & $99 \%(362 / 363)$ & $98 \%(385 / 390)$ & \\
\hline & [5] & [6] & N/A \\
\hline Ovine & $\begin{array}{c}95 \%(346 / 363) \\
{[10]}\end{array}$ & $\begin{array}{c}93 \%(362 / 390) \\
{[11]}\end{array}$ & $\begin{array}{c}97 \%(415 / 426) \\
{[13]}\end{array}$ \\
\hline Bovine & $\begin{array}{c}95 \%(346 / 363) \\
{[14]}\end{array}$ & $\begin{array}{c}92 \%(357 / 390) \\
{[23]}\end{array}$ & $\begin{array}{c}97 \%(415 / 426) \\
{[20]}\end{array}$ \\
\hline Porcine & $\begin{array}{c}92 \%(335 / 363) \\
{[15]}\end{array}$ & $\begin{array}{c}87 \%(338 / 390) \\
{[24]}\end{array}$ & $\begin{array}{c}90 \%(384 / 426) \\
{[21]}\end{array}$ \\
\hline Equine & $\begin{array}{c}85 \%(307 / 363) \\
{[16]}\end{array}$ & $\begin{array}{c}88 \%(344 / 390) \\
{[25]}\end{array}$ & $\begin{array}{c}79 \%(336 / 426) \\
{[22]}\end{array}$ \\
\hline
\end{tabular}

Similarities were calculated as a percent of identical nucleotides over the entire coding region.

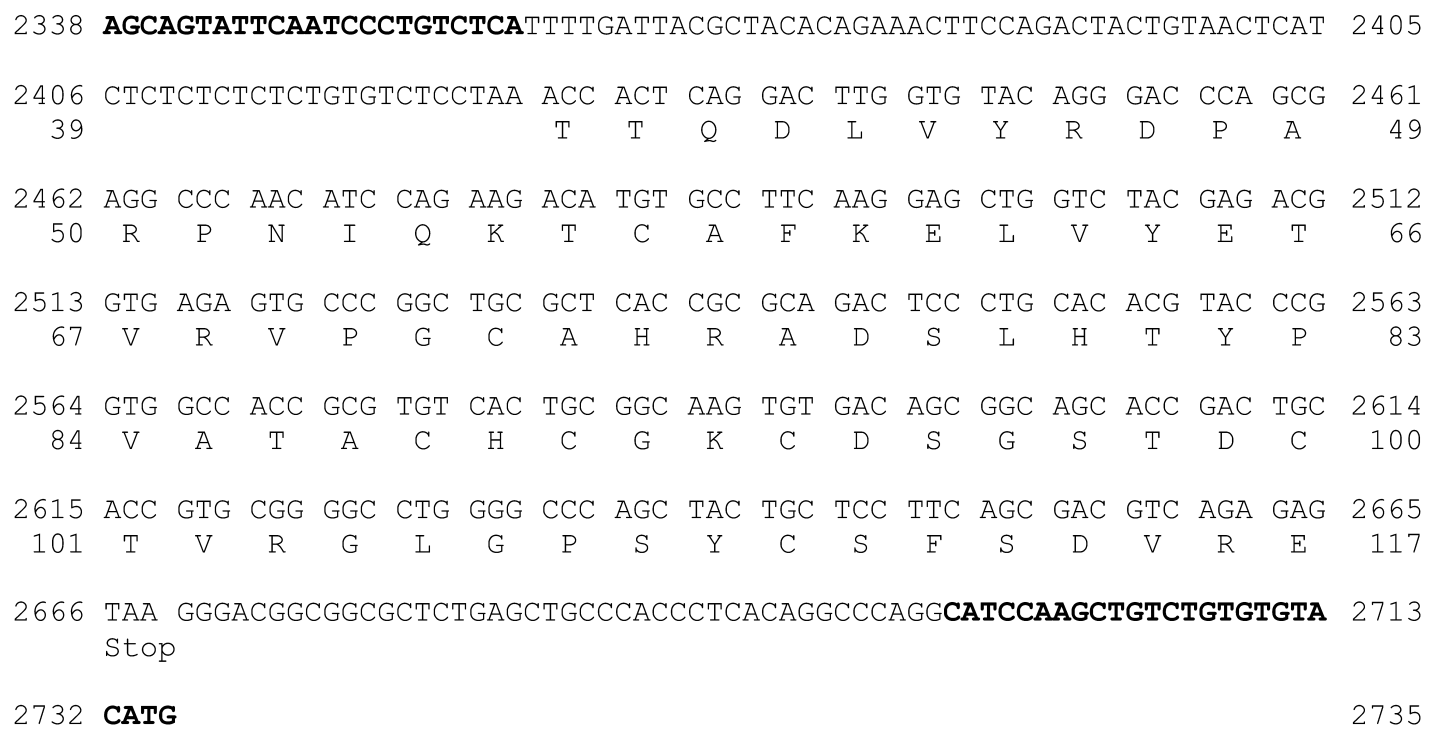

Fig. 2. Genomic nucleotide and deduced amino acid sequences of elk FSH $\beta$-subunit. The genomic nucleotide numbering is based on the NCBI S64745 ovine FSH- $\beta$ genomic sequence. The forward custom primer was designed from nucleotide positions 2338 to 2361 and the reverse custom primer was designed from nucleotide positions 2710 to 2735 .

deduced amino acid sequence similarity between elk and a sub-set of related species is shown in Table 3.

\section{Northern blot analysis}

Expression of the elk gonadotropin genes in elk and sheep tissues is shown in the Northern blot autoradiograms of Fig. 6 . The common $\alpha$-subunit, FSH $\beta$-subunit and LH $\beta$-subunit genes are expressed in the elk pituitary gland as mature transcripts of approximately 700, 1700 and 600 bases, respectively. Transcripts of these genes migrated to the same position as the corresponding mRNA expressed in the sheep pituitary gland. Expression of the gonadotropin genes was not observed in elk muscle tissue. GAPDH expression was observed in all samples. 
Table 3. Pituitary gonadotropin deduced amino acid sequences similarities between elk and a subset of related species

\begin{tabular}{lccc}
\hline & Elk $\alpha$-subunit & Elk FSH $\beta$-subunit & Elk LH $\beta$-subunit \\
& 120 a.a. & 129 a.a. & 141 a.a. \\
\hline Sika deer & $99 \%(119 / 120)$ & $96 \%(125 / 129)$ & - \\
Ovine & {$[5]$} & {$[6]$} & $89 \%(126 / 141)$ \\
& $95 \%(115 / 120)$ & $91 \%(118 / 129)$ & {$[13]$} \\
Bovine & {$[10]$} & {$[11]$} & $88 \%(125 / 141)$ \\
& $95 \%(116 / 120)$ & $90 \%(116 / 129)$ & {$[20]$} \\
orcine & {$[14]$} & {$[23]$} & $85 \%(111 / 141)$ \\
& $93 \%(112 / 120)$ & {$[115 / 129)$} & {$[21]$} \\
Equine & {$[15]$} & $87 \%(113 / 129)$ & $78 \%(109 / 141)$ \\
& $78 \%(94 / 120)$ & {$[25]$} & {$[22]$} \\
\hline
\end{tabular}

Similarities are expressed as percent of identical amino acids over the total for the specie shown in brackets.

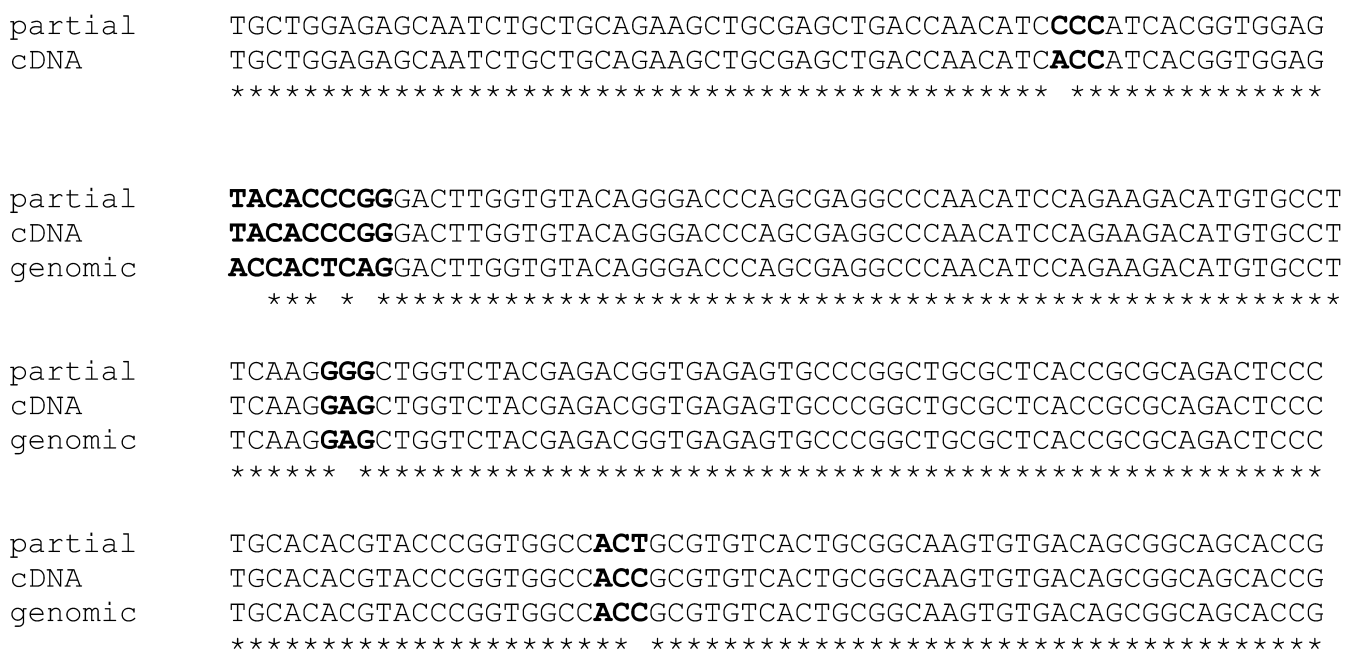

Fig. 3. Alignment of elk FSH $\beta$-subunit fragments amplified from 3 different animals. The stars represent the sequence, which is the same between the fragments. The codons where differences were observed are bolded. The first difference occurs at the codon encoding the amino acid at position 15, where the partial fragment would encode proline and the full-length cDNA would encode threonine. The codons encoding the amino acids at positions 39, 40 and 41 show differences among the DNA fragments sequenced. The partial and full-length fragments would encode tyrosine at position 39, whereas the genomic fragment would encode threonine. At position 40 , the nucleotide difference between the partial and full-length cDNA fragments compared to the genomic sequence does not result in an amino acid change. At position 41, the nucleotide difference would result in the genomic fragment encoding the amino acid glutamine, whereas the partial and full-length sequences would encode arginine. The full-length and genomic sequences would encode glutamic acid at amino acid position 61 , whereas the partial fragment would encode glycine. The nucleotide difference observed between the samples encoding amino acid 86, do not cause an amino acid change.

\section{Discussion}

We cloned and sequenced the elk pituitary gonadotropin $\alpha$ - and $\beta$-subunit cDNAs, and assessed expression of these genes by Northern blot analysis. The amplified elk $\alpha$-subunit cDNA is $95 \%$ similar, but 62 bases shorter, than the sheep $\alpha$ subunit cDNA reported by Bello et al. (1989). This discrepancy is due to the design of the forward $\alpha$ subunit primer, aimed to a sequence located close 


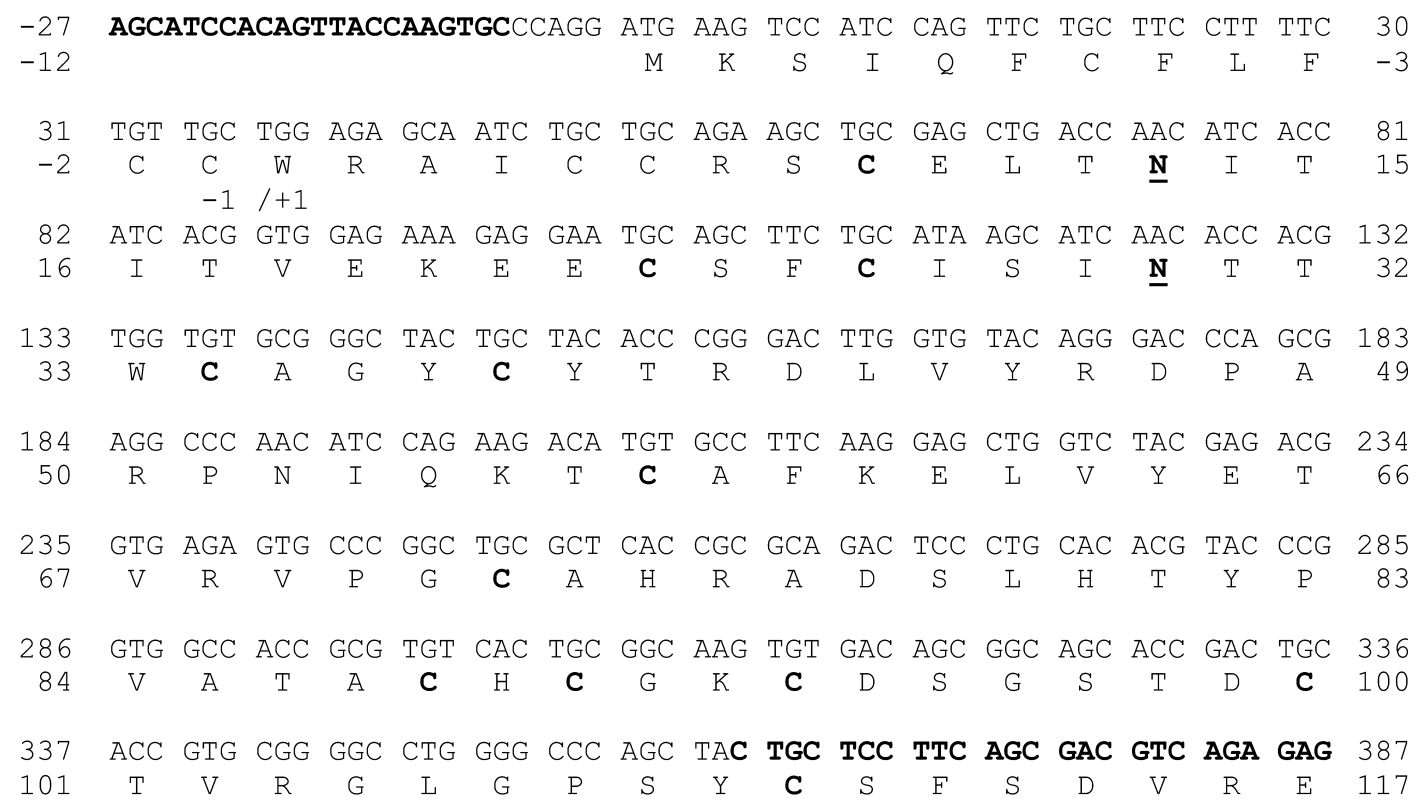

Fig. 4. cDNA nucleotide and deduced amino acid sequences of elk FSH $\beta$-subunit. The nucleotides of the $5^{\prime}$ UTR are designated with negative numbers and the first nucleotide of the ATG translational start codon as +1 . The forward custom primer was designed from nucleotide positions -27 to -6 . The reverse custom primer was designed from nucleotide positions 362 to 387 . Both primer sequences are shown in bold. The end of the signal peptide and the beginning of the mature protein amino acid sequence is designated at the $-1 /+1$ boundary. The proposed leader sequence is 12 amino acids in length. The FSH $\beta$-subunit is proposed to be $\mathrm{N}$-glycosylated at $\mathrm{Asn}^{13}$ and $\mathrm{Asn}^{30}$, shown in bold and underlined. Proposed proper folding involves 12 half cysteines shown in bold and located at positions 9, 23, 26, 34, 38, 57, 72, $88,90,93,100$ and 110 that form 6 disulfide bonds.

to the start codon. Thus, our elk $\alpha$-subunit cDNA clone has an incomplete $5^{\prime}$ UTR, compared to the ovine $\alpha$-subunit cDNA. During the course of this study, the glycoprotein $\alpha$-subunit [5] and FSH $\beta$ subunit [6] cDNA nucleotide sequences of the sika deer were reported. The presently reported elk cDNA shares $99 \%$ nucleotide similarity to the glycoprotein $\alpha$-subunit cDNA of the sika deer. Only one nucleotide difference was observed at position 11, where an adenine was reported for sika deer whereas in the elk we report a guanine. Using the cloned elk glycoprotein $\alpha$-subunit cDNA as a probe, a mature transcript size of approximately 700 bases was identified, which is consistent with the sheep glycoprotein $\alpha$-subunit mRNA reported by Bello et al. (1989). Thus, we consider that this cDNA corresponds to the elk common pituitary glycoprotein $\alpha$-subunit.

If the signal peptide of the elk $\alpha$-subunit is of the same length as reported for ovine [10], the elk $\alpha$ subunit cDNA would encode a mature protein of 96 amino acids. The nucleotide difference observed at position 11, translated into a difference in the fourth deduced amino acid. We report a cysteine for the elk, whereas a tyrosine was reported for sika deer, ovine, bovine, porcine and equine $[5,10,14-$ 16]. In addition, the forward primer we designed to amplify the elk $\alpha$-subunit cDNA biased the -24 and -23 deduced amino acids. Therefore, most likely the resulting deduced amino acids at -24 and -23 in the elk $\alpha$-subunit gene would be methionine and aspartic acid, which correspond to the amino acids reported for the other related species [5, 10, 14-16]. The hydrophobic residues in the signal peptide, including valine, alanine, leucine, and isoleucine, remain the same in the elk as in sika deer, ovine, bovine and porcine. The amino acid difference observed is a conserved change since tyrosine and cysteine are both uncharged polar residues. Therefore, the difference observed may not affect the biological activity of the hormone, since the signal peptide is cleaved from the nascent peptide.

The elk FSH $\beta$-subunit cDNA reported in this study is $98 \%$ similar, but 1175 bp shorter than the 


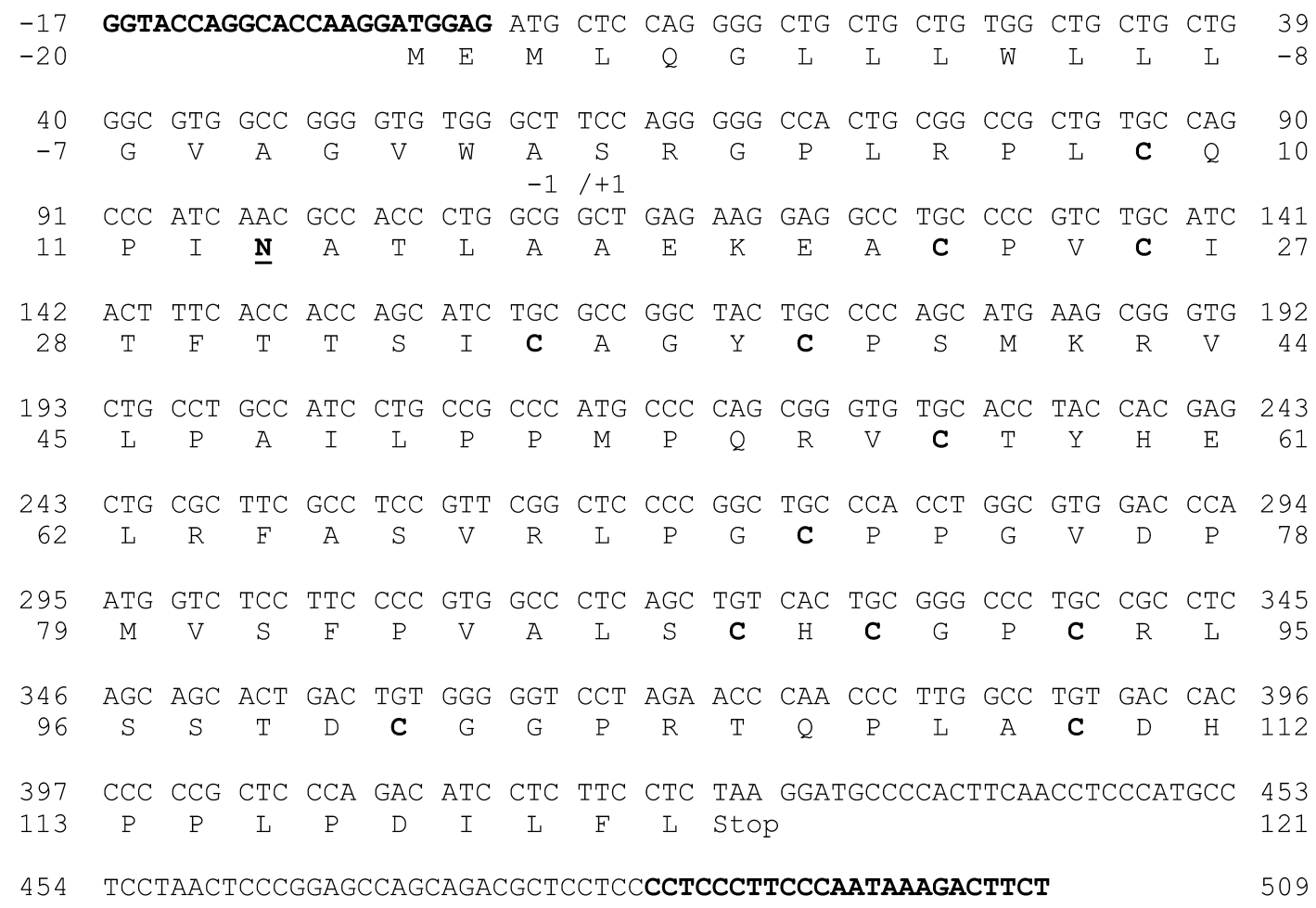

Fig. 5. cDNA nucleotide and deduced amino acid sequences of elk LH $\beta$-subunit. The nucleotides of the $5^{\prime}$ UTR are designated with negative numbers and the first nucleotide of the ATG translational start codon as +1 . The forward custom primer was designed from nucleotide positions -17 to +6 , overlapping the first two codons from the translational start site. The reverse custom primer was designed from nucleotide positions 485 to 509. Both primer sequences are shown in bold. The end of the signal peptide and the beginning of the mature protein amino acid sequence is designated as the $-1 /+1$ boundary. The proposed leader sequence is 20 amino acids in length. The LH $\beta$-subunit is presumed to be $N$ glycosylated at $\mathrm{Asn}^{13}$, shown in bold and underlined. Proposed proper folding involves 12 cysteines shown in bold and located at positions, 9, 23, 26, 34, 38, 57, 72, 88, 90, 93, 100 and 110 that form 6 disulfide bonds.

ovine FSH $\beta$-subunit cDNA reported by Mountford et al. (1989). This discrepancy is attributed to the forward FSH $\beta$-subunit primer, which hybridised at a site close to the start codon, and to the reverse FSH $\beta$-subunit primer 2, designed from the genomic elk FSH $\beta$-subunit clone, which hybridized to the last 9 codons of the gene. Thus, this cDNA does not include $29 \mathrm{bp}$ of the $5^{\prime}$ UTR, nor the $1144 \mathrm{bp}$ of the $3^{\prime}$ UTR compared to the ovine FSH $\beta$-subunit cDNA. The reported cDNA shares $98 \%$ nucleotide similarity to the FSH $\beta$-subunit cDNA of the sika deer. Using the cloned elk FSH $\beta$ subunit as a probe, a mature transcript size of approximately 1700 bases was identified, which is consistent with the reported size of the bovine FSH $\beta$-subunit mRNA [17]. Therefore, we conclude that the reported cDNA corresponds to the elk FSH $\beta$ - subunit.

The strategy used to clone the elk FSH $\beta$-subunit cDNA involved sequencing of a genomic fragment, from which we gained additional information on the structure of the gene. The elk FSH $\beta$-subunit genomic fragment presently reported contains $6 \mathrm{CT}$ microsatellite repeats in the intronic sequence amplified. This differs from the genomic sheep FSH $\beta$-subunit sequence [12], which contains 19 CT microsatellite repeats at the same location. If adequate variability in the number of these CT repeats were shown, this microsatellite could represent a marker for DNA fingerprinting in elk parentage testing [18].

Five nucleotide differences within the coding region of the FSH $\beta$-subunit were observed between elk and sika deer. The nucleotide 


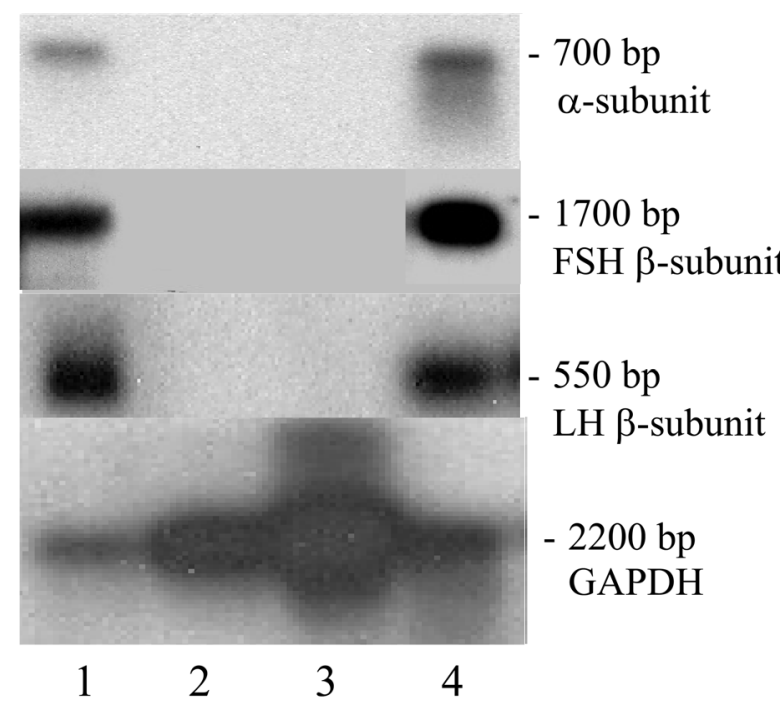

Fig. 6. Autoradiographs of Northern blot membranes hybridized with elk $\alpha$-subunit, FSH $\beta$-subunit, LH $\beta$ subunit and GAPDH cDNA probes. Lanes 1, 2, 3 and 4 were loaded with total RNA from sheep pituitary gland, elk muscle, Chinese hamster ovary cells and elk pituitary gland, respectively.

sequence of the FSH $\beta$-subunit cDNA was deduced from information obtained from three different animals, from which we amplified a truncated cDNA, a genomic fragment and a full-length cDNA. We observed discrepancies in the nucleotide sequences between these fragments, diagrammed in Fig. 3. The discrepancies reported could be due to amplification errors [19] or to genetic polymorphisms between different animals. The full-length cDNA would encode a peptide chain of 129 amino acids, of which 117 correspond to the mature protein.

The LH $\beta$-subunit cDNA we amplified is $96 \%$ similar, but 7 bp shorter than the ovine LH $\beta$ subunit cDNA reported by d'Angelo-Bernard et al. (1990). This discrepancy is due to the forward and reverse LH $\beta$-subunit primers, which did not target the complete $3^{\prime}$ or $5^{\prime}$ UTR sequences. Using the cloned elk LH $\beta$-subunit cDNA as a probe, a mature transcript size of approximately 550 bases was identified, which is consistent with the report for ovine [13]. Thus, we consider that this cDNA corresponds to the elk LH $\beta$-subunit. This cDNA would encode a peptide chain of 121 amino acids, of which 101 correspond to the mature protein, assuming that the signal peptide of elk would be the same length as reported for ovine [13]. The signal peptide is proposed to be the first 20 amino acids, which are cleaved to yield the mature protein. The forward LH $\beta$-subunit primer used compromises the methionine and glutamic acid amino acids at positions -20 and -19 . These amino acids were reported in the same positions in ovine, bovine, porcine and equine LH $\beta$-subunit $[13,20$. 22]. Therefore, we speculate that despite the introduced bias of the forward LH $\beta$-subunit primer, the elk LH $\beta$-subunit gene may encode for methionine and glutamic acid at positions -20 and -19 , respectively.

In summary, we cloned the elk glycoprotein $\alpha$ subunit and FSH and LH $\beta$-subunit cDNAs. Sequence and Northern blot analyses demonstrates high similarities between the gonadotropin hormones genes and their transcripts between elk, sika deer and sheep. The elk DNA sequences presently reported represent an addition to the growing collection of pituitary hormone genes for various vertebrates, which will facilitate evolutionary and phylogeneic studies of the gonadotropin genes.

\section{Acknowledgments}

We are indebted to Mr. Ryan J. Clark and Mr. Victor Bergen for kindly providing elk pituitary gland, and blood samples. The sheep pituitary glands and blood samples were generously provided by Dr. Norman Rawlings. This study was funded by the Natural Sciences and Engineering Research Council of Canada and the Saskatchewan Agricultural Development Fund in the form of research grants to PJC.

\section{References}

1. Pierce JG, Parsons TF. Glycoprotein hormones: structure and function. Ann Rev Biochem 1981; 50: 465-495.
2. Leung PC, Steele GL. Intracellular Signalling in the gonads. Endoc Rev 1992; 13: 476-498.

3. Li MD, Ford JJ. A comprehensive evolutionary 
analysis based on nucleotide and amino acid sequences of the $\alpha$ - and $\beta$-subunits of glycoprotein hormone family. J Endocrnol 1998; 156: 529-542.

4. Wallis M. Episodic evolution of protein hormones in mammals. J Mol Evol 2001; 53: 10-18.

5. Li Q, Guan H, Zhang L. Nucleotide Sequence of Cloned cDNA for $\alpha$ Subunit of Cervus nippon Follicle Stimulating Hormone. Heilongjiang, China. Direct Submission to NCBI GenBank, 2001; accession number AY066018.

6. Guan H-B, Li Q-Z, Zhang L. Nucleotide Sequence of Cloned cDNA for Beta Subunit of Cervus nippon Follicle Stimulating Hormone. Hei Longjiang, China. Direct Submission to NCBI GenBank, 2002; accession number AY156688.

7. Clark RJ, Valderrama X, Furlan, M, Chedrese PJ. Cloning and nuceotide sequence of the equine and elk pituitary pre-prolactin cDNA. Domest Anim Endocrinol 2003; 24: 367-376.

8. Chedrese PJ, Zhang D, Luu The V, Labrie F, Juorio AV, Murphy BD. Regulation of mRNA expression of $3 \beta$-hydroxy-5-ene steroid dehyrogenase in porcine granulosa cells in culture: a role for protein kinase-C pathway. Mol Endocrinol 1990; 4: 1532 1538.

9. Davis L, Kuehl M, Battey J. In: Basic Methods in Molecular Biology, edn 2. Norwalk, Connecticut, USA: Appleton \& Lange; 1994.

10. Bello PA, Mountford PS, Brandon MR, Adams TE. Cloning and DNA sequence analysis of the cDNA for the common alpha-subunit of the ovine pituitary glycoprotein hormones. Nucleic Acids Res 1989; 17: 10494.

11. Mountford PS, Bello PA, Brandon MR, Adams TE. Cloning and DNA sequence analysis of the cDNA for the precursor of ovine follicle stimulating hormone beta-subunit. Nucleic Acids Res 1989; 17: 6391.

12. Guzman K, Miller CD, Phillips CL, Miller WL. The gene encoding ovine follicle-stimulating hormone beta: isolation, characterization, and comparison to a related ovine genomic sequence. DNA Cell Biol 1991; 10: 593-601.

13. Brown P, McNeilly JR, Wallace RM, McNeilly AS, Clark AJ. Characterisation of the ovine LH betasubunit gene: the promoter directs gonadotropespecific expression in transgenic mice. Mol Cell Endocrinol 1993: 93; 157-165.

14. Goodwin RG, Moncman CL, Rottman FM, Nilson JH. Characterisation and nucleotide sequence of the gene for the common alpha subunit of the bovine pituitary glycoprotein hormones. Nucleic Acids Res 1983; 11: 6873-6882.
15. Kato Y, Ezashi T, Hirai T, Kato T. The gene for the common alpha subunit of porcine pituitary glycoprotein hormone. J Mol Endocrinol 1991; 7: 2734.

16. Stewart F, Thomson JA, Leigh SE, Warwick JM. Nucleotide (cDNA) sequence encoding the horse gonadotrophin alpha-subunit. J Endocrinol 1987; 115: 341-346.

17. Kim KE, Gordon DF, Maurer RA. Nucleotide sequence of the bovine gene for follicle-stimulating hormone $\beta$-subunit. DNA 1988; 7: 227-233.

18. Talbot J, Haigh J, Plante Y. A parentage evaluation test in North American Elk (Wapiti) using microsatellites of ovine and bovine origin. Anim Genet 1996; 27: 117-119.

19. Bracho MA, Moya A, Barrio E. Contribution of Taq polymerase-induced errors to the estimation of RNA virus diversity. J Gen Virol 1998; 79: 2921-2928.

20. Virgin JB, Silver BJ, Thomason AR, Nilson JH. The gene for the beta subunit of bovine luteinizing hormone encodes a gonadotropin mRNA with an unusually short 5'-untranslated region. J Biol Chem 1985; 260: 7072-7077.

21. Ezashi T, Hirai T, Kato T, Wakabayashi K, Kato Y. The gene for the beta subunit of porcine LH: clusters of GC boxes and CACCC elements. J Mol Endocrinol 1990; 5: 137-146.

22. Sherman GB, Wolfe MW, Farmerie TA, Clay CM, Threadgill DS, Sharp DC, Nilson JH. A single gene encodes the beta-subunits of equine luteinizing hormone and chorionic gonadotropin. $\mathrm{Mol}$ Endocrinol 1992; 6: 951-959.

23. Maurer RA, Beck A. Isolation and nucleotide sequence analysis of a cloned cDNA encoding the beta-subunit of bovine follicle-stimulating hormone. DNA 1986; 5: 363-369.

24. Kato Y. Cloning and DNA sequence analysis of the cDNA for the precursor of porcine follicle stimulating hormone (FSH) beta subunit. Mol Cell Endocrinol 1988; 55: 107-112.

25. Saneyoshi T, Min K, Shiota K. Equine folliclestimulating hormone beta-subunit. Toyko, Japan. Direct Submission to NCBI GenBank, 1999; accession number AB029157.

26. Min K, Shinozaki M, Miyazawa K, Nishimura K, Sasaki N, Shiota K, Ogawa T. Nucleotide Sequence of eCG $\alpha$-subunit cDNA and its expression in the equine placenta. J Reprod Develop 1994; 40: 301-305.

27. Li MD, Rohrer GA, Wise TH, Ford JJ. Identification and characterisation of a new allele for the beta subunit of follicle-stimulating hormone in Chinese pig breeds. Anim Genet 2000; 31: 28-30. 